\title{
Successful treatment of a hepatic abscess formed secondary to fish bone penetration by laparoscopic removal of the foreign body: report of a case
}

\author{
Mehmet Nuri Koşar, M.D., ${ }^{1}$ İhsan Oruk, M.D., ${ }^{1}$ Murat Burç Yazıcıoğlu, M.D., ${ }^{2}$ \\ Çiğdem Erol, M.D., ${ }^{3}$ Birgül Çabuk, M.D. ${ }^{4}$
}

\author{
1'Department of General Surgery, Acıbadem Hospital, Eskişehir; \\ ${ }^{2}$ Department of General Surgery, Derince Training and Research Hospital, Kocaeli; \\ ${ }^{3}$ Department of Infectious Diseases, Acıbadem Hospital, Eskişehir; \\ ${ }^{4}$ Department of Radiology, Acıbadem Hospital, Eskişehir
}

\begin{abstract}
Although foreign body ingestion is a common problem in children, it is also seen among adults. Perforation of the gut by a foreign body, followed by migration of the foreign body to the liver is quite rare. Most fish bone ingestions have uneventful outcome. However, occasionally, it can cause serious complications if the gastrointestinal tract is perforated. Herein, a case of liver abscess caused by a fish bone is reported. To the best of our knowledge, it is the first case in our country.
\end{abstract}

Key words: Fish bone; hepatic abscess; laparoscopic surgery.

\section{INTRODUCTION}

Hepatic foreign bodies are rare. ${ }^{[I]}$ Uncomplicated hepatic foreign bodies can be followed without surgical intervention. ${ }^{[1]}$ The majority of ingested foreign bodies pass through the gastrointestinal (GI) tract uneventfully. ${ }^{\left[{ }^{[}\right]}$In less than I\% of patients who develop gastrointestinal perforation have been reported. ${ }^{[2]}$ Endoscopy may be helpful if performed before foreign body migration and mucosal healing. ${ }^{[2]} \mathrm{UI}-$ trasonography and CT may help to diagnose these unusual presentations of migrating foreign bodies and to plan how to manage. Complicated hepatic foreign bodies as in our case should be removed by laparoscopy or laparotomy after the diagnosis.

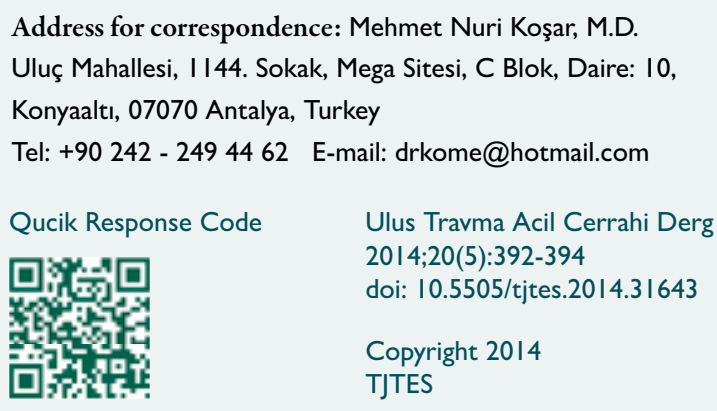

\section{CASE REPORT}

A 73-year-old female patient was admitted to the infectious diseases department due to high fever $\left(39^{\circ} \mathrm{C}\right)$. She was hospitalized with a diagnosis of pneumonia and antibiotherapy was started but high fever persisted. Abdominal computed tomography $(\mathrm{CT})$ was scheduled revealing a left lobe liver abscess (5-6 cm in diameter). A foreign body located at abscess-stomach neighborhood with a sharp surface was observed, showing a non-metal density (Fig. Ia).

The patient was questioned about her past medical history. She remembered that she had abdominal pain after eating something but could not tell what it was. Upper gastrointestinal endoscopy was performed; however, no luminal pathology was found. Later, laparoscopic operation and liver abscess drainage was performed. Fibrous structures were observed between the small curvature of the stomach and inferior line of left lobe of the liver, and the adhesions were dissected. After the drainage of the abscess, a fish bone was identified and removed laparoscopically. Operation was completed after inserting a drain at the operation area (Fig. Ib).

Postoperative antibiotherapy continued for three more days and the patient was discharged without experiencing any problems. 


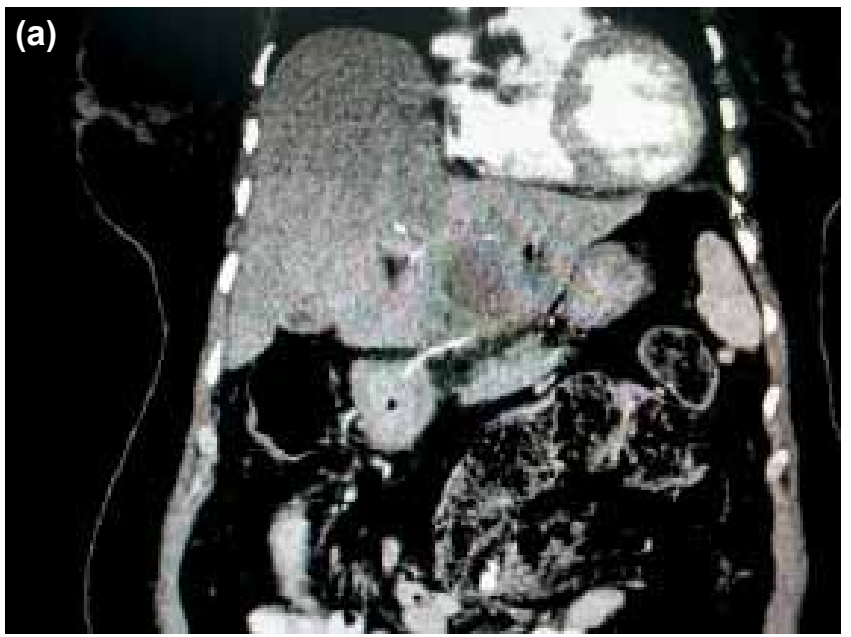

Figure 1. (a) Radiologic view of abscess and foreign body in the liver.

\section{DISCUSSION}

The majority of ingested foreign bodies pass through the gastrointestinal (Gl) tract uneventfully. ${ }^{[1,3]}$ In far-eastern countries, foreign body ingestion, especially that of the fish bone, is a common clinical problem of emergency departments. ${ }^{[2,4]}$ Fish bone in digestive tract may cause serious complications when compared to other foreign bodies. ${ }^{[5]}$ The most common symptoms are related to the location of the foreign body in the proximal esophagus. ${ }^{[6]}$ Gastrointestinal perforation have been reported in less than $1 \%$ of the cases and may cause peritonitis, localized abscess or inflammatory mass, bleeding or fistula. ${ }^{[1,7]}$ In some cases, pancreatitis, appendicitis, and liver abscesses have been reported. ${ }^{[8-10]}$

Hepatic foreign bodies are rare. ${ }^{[3]}$ Foreign bodies reach the liver by one of the three ways: direct penetration through the abdominal or thoracic wall, migration from the gastrointestinal tract, or through blood. ${ }^{\left[{ }^{\prime \prime}\right]}$ Majority of hepatic foreign bodies have been reported to penetrate into the liver by transmigration from the gastrointestinal tract (stomach, duodenum, and transverse colon). ${ }^{\left[{ }^{\prime \prime}\right]}$ In our patient, we could not find the trajectory of fish bone migration.

Rapid diagnosis and early intervention of gastrointestinal foreign bodies are required to prevent morbidity and mortality. [3] Plain radiography, ultrasound, CT, upper gastrointestinal series, upper endoscopy, colonoscopy, and laparotomy can be used to investigate foreign bodies in the gastrointestinal tract. [3] Traditionally, diagnosis and localization of the foreign body is made by plain abdominal radiograph. ${ }^{[12]}$ If the object is not recovered in stool, a radiograph is taken weekly to determine whether it has left the stomach and is progressing satisfactorily. ${ }^{[12]}$ Endoscopy may be helpful if performed before foreign body migration and mucosal healing. ${ }^{[7]}$ In our case, endoscopy was not helpful for the event had taken place considerably a long time ago. Ultrasonography and CT may help to diagnose these unusual presentations of migrating foreign bodies and plan the management. CT gives excellent results in the de-

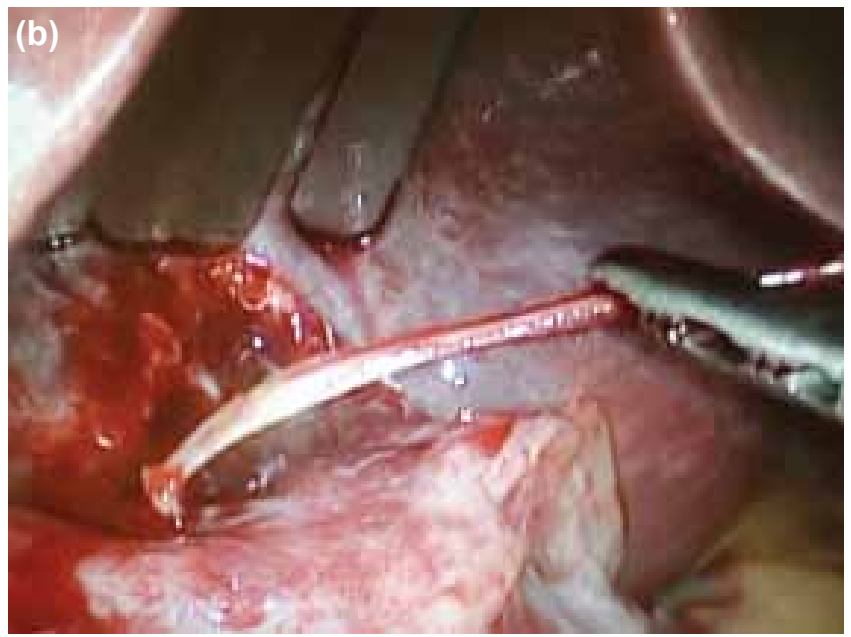

(b) Laparoscopic view of abscess and foreign body in the liver.

tection of foreign bodies because of its high resolution and accuracy. ${ }^{[7]}$ Ultrasound should be considered as an alternative method to demonstrate metallic foreign bodies. In our case, ultrasound was less sensitive than $\mathrm{CT}$ since the foreign body had a non-metallic density.

Uncomplicated hepatic foreign bodies can be followed without surgical intervention. ${ }^{[I]}$ However, complicated hepatic foreign bodies, as in our case, should be removed by laparoscopy or laparotomy, and hepatic abscess drainage or hepatic segmentectomy must be done in the same séance, if necessary.

\section{Conflict of interest: None declared.}

\section{REFERENCES}

1. Crankson SJ. Hepatic foreign body in a child. Pediatr Surg Int 1997;12:426-7. CrossRef

2. Santos SA, Alberto SC, Cruz E, Pires E, Figueira T, Coimbra E, et al. Hepatic abscess induced by foreign body: case report and literature review. World J Gastroenterol 2007;13:1466-70. CrossRef

3. Lee KF, Chu W, Wong SW, Lai PB. Hepatic abscess secondary to foreign body perforation of the stomach. Asian J Surg 2005;28:297-300. CrossRef

4. Nandi P, Ong GB. Foreign body in the oesophagus: review of 2394 cases. Br J Surg1978;65:5-9. CrossRef

5. Chung CH, Lau CK, Chow TL. Swallowed foreign bodies in adults. HK Pract 1991;13:1805-6.

6. Singh B, Kantu M, Har-El G, Lucente FE. Complications associated with 327 foreign bodies of the pharynx, larynx, and esophagus. Ann Otol Rhinol Laryngol 1997;106:301-4.

7. Ngan JH, Fok PJ, Lai EC, Branicki FJ, Wong J. A prospective study on fish bone ingestion. Experience of 358 patients. Ann Surg 1990;211:45962. CrossRef

8. Dabadie A, Roussey M, Betremieux P, Gambert C, Lefrancois C, Darnault P. Acute pancreatitis from a duodenal foreign body in a child. J Pediatr Gastroenterol Nutr 1989;8:533-5. CrossRef

9. Sukhotnik I, Klin B, Siplovich L. Foreign-body appendicitis. J Pediatr Surg 1995;30:1515-6. CrossRef

10. Broome CJ, Peck RJ. Hepatic abscess complicating foreign body perforation of the gastric antrum: an ultrasound diagnosis. Clin Radiol 2000;55:242-3. CrossRef

11. Nishimoto Y, Suita S, Taguchi T, Noguchi S, Ieiri S. Hepatic foreign body - a sewing needle - in a child. Asian J Surg 2003;26:231-3. CrossRef

12. Spina P, Minniti S, Bragheri R. Usefulness of ultrasonography in gastric foreign body retention. Pediatr Radiol 2000;30:840-1. CrossRef 


\section{OLGU SUNUMU - ÖZET}

\section{Balık kılçı̆̆ı penetrasyonuna bağlı oluşmuş karaciğer apsesinin} laparoskopik olarak başarılı tedavisi: Olgu sunumu

\section{Dr. Mehmet Nuri Koşar, ${ }^{1}$ Dr. İhsan Oruk, ${ }^{1}$ Dr. Murat Burç Yazıcıoğlu, ${ }^{2}$ Dr. Çiğdem Erol, ${ }^{3}$ Dr. Birgül Çabuk ${ }^{4}$}

${ }^{1}$ Acıbadem Hastanesi, Genel Cerrahi Kliniği, Eskişehir;

${ }^{2}$ Derince Eğitim ve Araştırma Hastanesi, Genel Cerrahi Kliniği, Kocaeli;

${ }^{3}$ Acıbadem Hastanesi, Enfeksiyon Hastalıkları Kliniği, Eskişehir;

${ }^{4}$ Acıbadem Hastanesi, Radyoloji Kliniği, Eskişehir

Yabancı cisim yutulması özellikle çocuklarda olmak üzere her yaş grubunda görülebilir. Çoğu yabancı cisim herhangi bir hasara yol açmadan gastrointestinal sistemi boydan boya geçer. Yutulan bir yabancı cismin karaciğere geçmesi çok nadir görülür. Fakat bazen gastrointestinal bütünlüğü bozan yabancı cisimler ciddi komplikasyonlara yol açarlar. Bu yazıda balık kılçığı nedeni ile oluşmuş karaciğer apsesinden bahsetmekteyiz. Bu bildiğimiz kadarı ile ülkemizde bildirilen ilk olgudur.

Anahtar sözcükler: Balık kılçı̆̆; karaciğer apsesi; laparoskopi.

Ulus Travma Acil Cerrahi Derg 2014;20(5):392-394 doi: 10.5505/tjtes.2014.31643 